\title{
Helping to Make Connections: Emphasizing the Role of the Syllabus
}

\section{Barbara J. Millis}

The University of Maryland University College

In a widely respected article, "Professors, Students, and the Syllabus," Sharon Rubin argues that the syllabus is a means of "connecting" students and teachers. Her article, which first appeared on the "Point of View" page of the Chronicle of Higher Education, concludes with these encouraging words:

If students could be persuaded that we are really interested in their understanding the material we offer, that we support their efforts to master it, and that we take their intellectual struggles seriously, they might respond by becoming more involved in our courses, by trying to live up to our expectations, and by appreciating our concern. Then the real work of learning can begin. $(1985$, p. 56)

Oddly enough, despite the importance of the syllabus, a random check of five highly respected "how to teach" books (Eble, 1988; Erickson, 1984; Fuhrmann and Grasha, 1983; Lowman, 1984; and McKeachie, 1978) reveals that, although course planning is emphasized in each, only McKeachie discusses the syllabus in any depth or even includes it in the table of contents. Overviews of the syllabus do appear in an essay entitled "The First Day of Class" (Wolcowitz, 1982) and in various publications and articles produced by campus teaching centers and academic departments (Davis, 1988; Janes \& Hauer, 1988; Talarico, 1988; Wilkerson, 1978). 


\section{Emphasizing the Importance of the Syllabus at University College}

The faculty development program at The University of Maryland University College emphasizes the value of a well-constructed, wellthought-out syllabus through several approaches: (a) distribution of a Syllabus Construction Handbook to all new faculty; (b) syllabus solicitation and review; (c) information about the syllabus in faculty publications; (d) workshops focused on the syllabus; and (e) emphasis on the syllabus in two key components of the faculty development program.

\section{Distribution of a Syllabus Construction Handbook}

All new faculty members receive a copy of a Syllabus Construction Handbook (1986), a seven-page modification of The Compleat Syllabus: Your Ticket to a Successful Course (Millis, 1983), which is given to all faculty in the Asian Division of The University of Maryland University College. The Handbook is included in the information packet, "The Faculty Survival Kit," which is distributed at the once-a-semester New Faculty Orientations. Those unable to attend orientation are mailed a copy of the "Kit," so that all lecturers receive the same crucial information. At all orientation sessions, the Assistant Dean, Faculty Development mentions the Syllabus Construction Handbook and reinforces the importance of the syllabus for adult learners. At the Spring 1989 orientation, for example, all four faculty panelists who provided advice and an overview of teaching at University College repeatedly emphasized the role of the syllabus. One panelist stressed its value in eliminating or defusing student complaints.

\section{Syllabus Solicitation and Review}

All University College lecturers are asked to send copies of their course syllabi to the Office of Faculty Development. These syllabi are reviewed and then kept on file for other lecturers, particularly those new to the program, who want to see how their colleagues structure their classes. Lecturers who fail to turn in syllabi are reminded at mid-semester that their document file is incomplete. The follow-up letter stresses the positive nature of their contributions, including the value of their syllabi to other lecturers, and the benefits they will receive from the syllabus review conducted by the Office of Faculty Development.

To encourage faculty to submit their syllabi and also to encourage a carefully crafted product, all lecturers receive a Faculty Syllabus Checklist 
(see appendix) that helps them to determine whether their syllabus contains all the essential components. The checklist also enables the Office of Faculty Development to provide a quick content-related syllabus review.

\section{Information about the Syllabus in Faculty Publications}

The importance of the syllabus is also emphasized in faculty publications. The Faculty Guide, for instance, outlines the required minimum content for all University College syllabi. These are: course title, number and section; time and place of class meeting; instructor's name, telephone number(s), and the best time to call; textbooks, including author, title, publisher, edition (and cost, if known); grading procedures that include the criteria and percentage breakdown/value of each component of the final grade; policies on attendance, late work, make-up work and extra credit; a list of assignments, including number and types of texts/exams, the due dates of assignments, and each assignment's weight in the final grade.

The Faculty Guide also recommends including additional information such as: course objectives; the role of the course in the University College or departmental curriculum; prerequisites; expectations for student performance, including standards of writing competence; a date-bydate list of assignments and readings; a description of assignments, with details on format, content, and so on; a bibliography of recommended readings; a description of how class sessions will be conducted.

Every issue of Faculty Focus, the faculty newsletter, makes some reference to the syllabus, usually by citing innovative approaches in specific syllabi, such as the use of quotations to add interest and highlight the content of a statistics course. A recent issue, in fact, featured the syllabus, with three student-written articles under the headline, "Salute to the Syllabus."

The opening paragraphs of two of the articles suggest the importance of a well-constructed syllabus to adult learners:

To an instructor, a syllabus may be simply a list of dates and assignments. However, to an adult student, a syllabus serves at least two vital purposes. First, the syllabus directly reflects the instructor's goals, direction, commitment, and organization. Second, the syllabus directs the student's life for the length of the course. (McDaniel, 1988)

Many students think of each course as an expedition into unexplored territory, and the course syllabus as the map which defines the 
destination and how to reach it. As such, the importance of the syllabus to the adult learner cannot be underestimated. (Cunningham, 1988)

\section{Workshops Focused on the Syllabus}

The importance of the syllabus is also emphasized by specific workshops that highlight its vital role. For a number of years, a workshop entitled "Syllabus Construction on Word Processors" was offered just prior to the beginning of each semester. The workshop was well-attended, but during the past academic year, an alternate workshop entitled "Getting Started: The Basics of Course Preparation and Presentation," has been scheduled instead; too many instructors attending the former workshop expected to emerge from a three-hour session with newly acquired word processing skills and also a completely developed course syllabus. During the "Getting Started" workshop, which includes various handouts, lecturers critique sample syllabi and discuss their own approaches.

\section{Emphasis on the Syllabus in Two Key Components of the Faculty Development Program}

The syllabus is emphasized in two programs at University College focused on improvement of teaching and recognition of excellence in the classroom. A systematic Peer Visitation Program has been in place at University College since 1985. Peer visitors are asked to obtain copies of current syllabi from the lecturers they visit and to discuss their components. A section on the Classroom Visitation Form calls for a thorough critique of the syllabus in view of University College's requirements; this critique also includes the review of other instructional materials emphasized by Seldin (1984) as important to faculty evaluation.

An award-winning Excellence in Teaching Award program also highlights the syllabus. A student/faculty/administration selection committee examines syllabi for all nominees, using a rating form designed to help them systematically evaluate the material assembled in thick teaching portfolios. During the deliberations to determine last year's two winners, the syllabus was mentioned frequently and in at least one case was a deciding final factor. 


\section{Refinements to the University College Program}

\section{Revision of The Compleat Syllabus}

Following a revision that will incorporate examples from University College's statewide undergraduate program's current syllabi, The Compleat Syllabus, a 32-page booklet, will be distributed to all faculty. At present, they receive the abbreviated version, which is entitled the Syllabus Construction Handbook.

The body of The Compleat Syllabus discusses each component of the syllabus, giving the rationale for including each section and providing examples from current syllabi. The booklet links each syllabus component to sound advice about teaching. For example, the section on "Testing and Grading Policies" says:

Students are eager to know not only the course requirements (field trips, papers, exams, and so forth), but also how much each of these will weigh in the final evaluation. Thus it is important to spell out exactly how you will determine final grades. Because learning theory indicates that students prepare differently for essay and so-called "objective" exams, you must indicate the nature, as well as the subject matter, of the exams. Be as specific as possible about what you will cover (e.g., "Chapters 1-10, plus the lecture material") and how you will test (multiple choice, short answer, essay, and so forth), so that students can prepare efficiently. Tests should be a part of the learning process, constantly reinforcing your objectives, assignments, and classroom activities. Nothing leads to more student frustration and wasted effort than the professor who smiles smugly and says, "I want you to know everything." (Millis, 1983, pp. 16-17)

Appendices include sections on syllabus format, "Using Creative Quotations," and "Free Samples" (examples of effective syllabi).

\section{Revision of the Syllabus Review Process}

A recent pilot project on syllabus review initiated by the nationally recognized Paralegal Program may well provide a model more effective than the current syllabus review process used by the Office of Faculty Development. The review form in particular seems to be a helpful way to provide feedback to faculty and could be used in conjunction with the Faculty Syllabus Checklist now distributed to all lecturers. To initiate the review, the Program Manager sent a letter to all Paralegal faculty announcing the project and the role of its coordinator, a highly respected 
lecturer in the paralegal program who received University College's prestigious Excellence in Teaching Award for the 1988-89 academic year. The letter emphasized the importance of the syllabus to adult learners and presented the project in a positive way.

When the coordinator returned her critique of each instructor's syllabus, she included a personal letter reinforcing the nature and intent of the syllabus review project and explaining her approach:

My approach to this task was not only to look for inclusion of the necessary basic elements, but also to focus on the clarity and thoroughness of the information within specific components. These components are:

1. Course description and objectives-which provide an overview of the subject matter of the course and the knowledge and skill competencies which the student can achieve.

2. Class schedule-which gives information about the subject matter of each class, preparatory readings, and other work which will help the student to understand the content.

3. Evaluation plan-which describes the evaluation tools and notes relevant dates and policies regarding make-ups, lateness and academic integrity.

4. Grading Policy-which indicates the weight of each evaluation tool and how the final grade is determined including whether attendance or class participation is a factor. (A. Lagnese, personal letter, November 1988)

The coordinator's comments, which were handwritten on the review form, were personal, positive, and professional. Typical remarks were:

Very nice! You may want to personalize this section by directing it to the individual student.

Readings? The more information on the subject matter of each class, the better able the students are to structure their study.

Since you are using the Study Guide to the text, you may want to refer to it with the assigned readings.

I can't determine the six full assignments. Do you collect the homework notebook?

Are the writing assignments given in writing? If so, they can be appended to the syllabus.

Policies on lateness, make-up work, academic integrity? 
It is not evident how the final grade is determined.

In the semester following this review, the Program Manager noticed that most lecturers had indeed expanded and/or clarified their syllabi. They had apparently followed through on most of her suggestions. A more systematic follow-up study will be conducted this summer.

Based on the success of this Paralegal Program pilot project, the Office of Faculty Development will begin with the summer term a more rigorous syllabus review process for faculty in all disciplines. A letter notifying lecturers of this upgraded critiquing service emphasized the value of "constructive, useful feedback ... to help strengthen communication with students and, in some cases, to head off potential problems." A qualitative, rather than a quantitative, approach will ensure that syllabus components are not only present, but are also effective. To emphasize the positive nature of the review process, congratulatory letters will go to lecturers with unusually well-conceived, well-constructed syllabi.

\section{Implications for Other Institutions}

Many academic departments emphasize the syllabus, but usually within the context of promotion and tenure considerations, an approach emphasizing the "stick" rather than the "carrot." There are many positive, practical reasons for faculty to invest in an effective syllabus, however; with the renewed emphasis on the quality of undergraduate education, departments have many good reasons to encourage improvement. Campus-wide faculty development centers can take the initiative by offering a number of syllabus-related services to departments. Workshops, newsletters, "how-to" booklets, and critiques can all be useful. Critiques offered by faculty development centers obviously should not review syllabus content, which is a departmental concern. They should focus instead on the clarity and thoroughness of the various components of the syllabus and pinpoint missing information.

Even without departmental involvement, a faculty development/teaching effectiveness center can offer this "critiquing service" to individual faculty members interested in their own professional development. Creating publications similar to The Compleat Syllabus takes an investment in time, effort, and financial resources, but in the long run such publications reinforce the institution's commitment to high-quality teaching, student learning, and the "connections" between faculty and students.

Perhaps the importance of these teaching/learning connections can be emphasized with an analogy. Master chefs can spend hours or even 
days planning and executing the most superb culinary delights, but unless someone hands the diners a well-crafted menu, their Tournedos Rossini or Poulet à la Niçoise may well languish - untasted, untouched.

\section{References}

Cunningham, R. (1988). The importance of the syllabus. Faculty Focus, 6(2), 2-3.

Davis, S. K. (Ed.). (1988). Guidesheet for syllabus construction. Unpublished manuscript, The University of Maryland, College of Business and Management.

Eble, K. E. (1988). The craft of teaching: A guide to mastering the professor's ant (2nd ed.). San Francisco: Jossey-Bass.

Erickson, S. C. (1984). The essence of good reaching: Helping students leam and remember what they learm. San Francisco: Jossey-Bass.

Fuhrmann, B. S., \& Grasha, A. F. (1983). A practical handbook for college teachers. Boston: Little, Brown.

Janes, J., \& Hauer, D. (1988). Now what? Readings on surviving (and even enjoying) your first experience at college teaching (2nd ed). Littleton, MA: Copley Publishing Group.

Lowman, J. (1984). Mastering the techniques of teaching San Francisco: Jossey-Bass.

McDaniel, S. V. (1988). The syllabus: What it should be. Faculty Focus, 6(2), 1-2.

McKeachie, W. J. (1978). Teaching tips: A guidebook for the beginning college teacher. Lexington, MA: D. C. Heath.

Millis, B. J. (1983). The compleat syllabus. Your ticket to a successful course (2nd ed.). (Available from The University of Maryland, University College, Office of Faculty Development.)

Rubin, S. (1985, August 7). Professors, students, and the syllabus. Chronicle of Higher Education, p. 56.

Seldin, P. (1984). Changing practices in faculy evaluation: A critical assessment and recommendations for improvement. San Francisco: Jossey-Bass.

Syllabus construction handbook. (1986). (Available from The University of Maryland, University College, Office of Faculty Development.)

Talarico, S. (1988). The importance of preparing and using course syllabi. Teaching at $U G A$, 6(2), p. 5.

Wilkerson, L., \& McKnight, R. T. (1978). Writing a course syllabus: A self-study packet for college teachers. Murray, KY: Center for Enhancement of Teaching Effectiveness, Murray State University.

Wolcowitz, J. (1982). The first day of class. In M. M. Gullette (Ed.), The art and craft of teaching (pp. 10-24). Cambridge: Harvard University Press. 


\section{Appendix}

\section{Faculty Syllabus Checklist}

These important components of an effective syllabus should be included in all University College syllabi. You might want to use this as a handy checklist.

\section{Information About Instructor}

- Name

_ Phone number(s)

_ Times when students may contact you

\section{Course Information}

- Heading (The University of Maryland University College)

_Course number, section, title, location

_ Required text(s) - title(s), author(s), edition(s)

_ Recommended books (not required)

_Course description and/or objectives

\section{Schedule Information}

For the date of each class meeting, specify: the subject matter/topics to be covered (e.g., lectures, field trips, guest lecturers, etc.) and the pre-class readings and other nongraded assignments due.

_ Graded assignment due dates, preferably highlighted in bold or capitalized (e.g., homework, quizzes, papers, projects)

_ Exam dates, preferably highlighted

\section{Grading Information}

- Course requirements (exams, quizzes, projects, papers) and the proportion each counts towards the final grade. Discuss the content and format of each requirement, including examinations, unless you provide other instructions. If class participation is factored in, please explain how you will evaluate it.

_ Grading scale and standards 
244

To Improve the Academy

Additional Components

_Policies regarding late work and make-up exams

_ A statement regarding academic integrity

A statement about the UMUC policy of requiring students to produce photo identification before taking an examination

Attendance policy

- Unique class procedures/structures, such as cooperative learning exercises, panel presentations, case study methods, class journals or learning logs, etc. 